\title{
Assessment of Hematological Parameters Before and After Adjuvant Chemotherapy in Patients with Colorectal Cancer
}

\section{Kolorektal Kanserli Hastalarda Adjuvan Kemoterapi Öncesi ve Sonrasında Hematolojik Parametrelerin Değerlendirilmesi}

\author{
Fevzi Coşkun Sökmen¹, Benan Kasapoğlu², Ahmet Yozgat ${ }^{2}$, Hüseyin Engin ${ }^{3}$ \\ ${ }^{1}$ University of Health Sciences, Dr Abdurrahman Yurtaslan Oncology Education and Research Hospital, \\ Department of Internal Medicine, Ankara, Turkey \\ ${ }^{2}$ University of Health Sciences, Dr Abdurrahman Yurtaslan Oncology Education and Research Hospital, \\ Department of Gatroenterology, Ankara, Turkey \\ ${ }^{3}$ Bulent Ecevit University Practice and Research Hospital, Medical Oncology, Zonguldak, Turkey
}

Dergiye Ulaşma Tarihi: 21/08/2019 Dergiye Kabul Tarihi: 26/09/2019 Doi: 10.5505/aot.2019.20982

\begin{abstract}
ÖZET
GÍRIŞ ve AMAÇ: Bu çalışmada kolorektal kanserli hastalarda adjuvan kemoterapi tedavisi sonrasında hematolojik parametrelerdeki değişiklikleri değerlendirmeyi amaçladık.

YÖNTEM ve GEREÇLER: Kolorektal kanser tanısı konan toplam 140 vakada değerlendirilmiş ve bu hastalardan 57'sine adjuvan kemoterapi verilmiştir. Adjuvan kemoterapi sonrası tam kan sayımı parametrelerindeki değişiklikler değerlendirildi.

BULGULAR: Katılımcıların 67'si (\% 47.9) kadın, 73'ü (\% 52.1) erkek idi, yaş ortalamaları $62.13 \pm 1.11$ yıl idi. En sık görülen tümör yerleşimi rektumdu (\% 45.7). Bu hastalardan 57'si adjuvan kemoterapi (\% 40.7) aldı, en sık uygulanan kemoterapi rejimi Mayo rejimi (\% 84.2) idi. Olgularımızın \% 27.9'unda tanı anında metastaz vardı. Klinik takip sırasında hastaların\% 10.7'sinde lokal nüks ve\% 7.8'inde metastaz vardı. Hemoglobin (HGB) düzeyleri hem kan transfüzyonu yapılan hastalarda hem de yapılmayanlarda anlamlı bir düşüş gösterdi, ancak bu daha önce transfüzyonu olmayan hasta grubunda daha belirgindi $(\mathrm{p}=0.002)$. Yardımc1 kemoterapiyi takiben, beyaz kan hücresi değerleri (WBC), ortalama eritrosit hacimleri (MCV) ve trombosit (PLT) seviyelerinin, modifiye edici bileşenlerle (metastaz gelişimi, kemoterapi uygulama süresi, kan transfüzyonu) herhangi bir etkileşim olmadan önemli ölçüde azaldığı bulundu. (Sırasıyla p değerleri 0.002, 0.001 ve 0.001), ayrıca kırmızı hücre dağılım genişliği (RDW) önemli ölçüde artmıştır ( $\mathrm{p}=0.001)$.

TARTIŞMA ve SONUÇ: Hgb, MCV, WBC ve trombosit seviyelerinde anlamlı bir azalma ve adjuvan kemoterapi sonrası RDW'de anlamlı bir artış vardı ve bu değişiklikler metastaz varlığından veya kemoterapi süresinden etkilenmedi. Kan parametrelerinde bu değişikliklerin hastaların prognozu ile ilişkisi ileriki çalışmalarda araştırılmalıdır.
\end{abstract}

Anahtar Kelimeler: kolorektal kanser, beyaz kan hücresi değerleri, ortalama eritrosit hacmi, trombosit, kırmızı hücre dağılım genişliği

ABSTRACT
INTRODUCTION: In this study we aimed to evaluate the alterations in hematological parameters due to the adjuvant chemotherapy treatment in patients with colorectal cancer.

METHODS: In a total of 140 cases diagnosed with colorectal cancer were evaluated and among those patients 57 received adjuvant chemotherapy. Alterations in complete blood count parameters after adjuvant chemotherapy were evaluated.

RESULTS: Among participants, 67 (47.9\%) were women and 73 (52.1\%) were men with a mean age of $62.13 \pm$ 1.11 years. The most common tumor localization was rectum (45.7\%). Among these patients 57 received adjuvant chemotherapy (40.7\%), the most frequently implemented chemotherapy regimen was Mayo regimen (84.2\%). $27.9 \%$ of our cases had metastasis at the time of diagnosis. During clinical follow-up $10.7 \%$ of the patients had local relapse and $7.8 \%$ had metastasis. Hemoglobin (HGB) levels displayed a significant decrease both in patients who received blood transfusion or not, however this was more evident in the group of patients 
with no previous transfusion $(\mathrm{p}=0.002)$. Following the adjuvant chemotherapy, white blood cell values (WBC), mean erythrocyte volumes (MCV) and thrombocyte (PLT) levels were found to decrease significantly without any interaction with modifying components (metastasis development, chemotherapy implementation duration, blood transfusion) ( $\mathrm{p}$ values $0.002,0.001$ and 0.001 respectively) while red cell distribution width (RDW) had increased significantly $(\mathrm{p}=0.001)$.

DISCUSSION AND CONCLUSION: There was a significant decrease in Hgb, MCV, WBC and platelet levels and a significant increase in RDW after adjuvant chemotherapy and these alterations were not affected by the presence of metastasis or duration of chemotherapy. The association of these alterations in blood parameters with the prognosis of patients should be investigated in further studies

Keywords: colorectal cancer, white blood cell values, mean erythrocyte volume, thrombocyte, red cell distribution width

\section{INTRODUCTION}

Colorectal cancer (CRC) is the third most common cancer worldwide. Fortunately, in localized disease the 5-year survival rate is about $90 \% \quad$ (1). Chemotherapyinduced alterations in complete blood count may cause many significant problems in clinical practice. Anemia, neutropenia and thrombocytopenia induced by chemotherapy regimens may cause life-threatening complications such as severe infections and hemorrhagic complications. Moreover, these side effects may also necessitate dose reduction and/or delay in schedules of chemotherapy treatment $(2,3)$.

In this study we aimed to evaluate the alterations in hematological parameters due to the adjuvant chemotherapy treatment in patients with colorectal cancer.

\section{MATERIAL AND METHOD}

In this retrospective study, socio-demographic and clinical characteristics of 140 patients with colorectal cancer who were admitted to Zonguldak Karaelmas University Medical Faculty Practice and Research Hospital Medical Oncology Outpatient Clinic were evaluated. The study was approved by the local ethics committee (Date: 31.05.2007, No: B.30.2.ZKÜ 0.70.10.00/001-462-6059).

In a total of 140 cases diagnosed with colorectal cancer were evaluated. Among these patients 57 received adjuvant chemotherapy $(40.7 \%)$, and the most frequently implemented chemotherapy regimen was Mayo regimen (84.2\%), 5-fluorouracil-folinic acid + Folinic acid (5 FU-FA) for 6 cycles. Patients' demographic characteristics, localization and size of the tumor, local recurrence and / or metastasis location and date, in patients who had received adjuvant chemotherapy complete blood count values before and after treatment were recorded.

\section{Statistical analyses}

Descriptive statistics of the data are given as number, \% frequency and mean \pm Standard Deviation (SD) or median value. KolmogorovSmirnov test was used in the normality test of the variables. The differences in whole blood count parameters before and after chemotherapy and changes in tumor markers were examined by repeated covariance analysis. In this analysis, whether or not metastasis developed, whether or not blood transfusion was performed and the duration of chemotherapy were taken as the common variables. Data analyzed using SPSS software for windows (IBM SPSS 11.5, IBM Corp, NY). The significance level was set at $\mathrm{p}<0.005$.

\section{RESULTS}

In a total of 140 patients ( 73 male and 67 female) with colorectal cancer were investigated. The ages of the patients ranged from 29 to 89 years, and the mean age of the patients was $62.13 \pm 1.11$ years. Among patients $47.9 \%$ were smoking. Localizations of the tumors are summarized in Table 1.

Table 1. Localizations of the tumors

\begin{tabular}{|l|l|l|}
\hline Localization & Number & \% \\
\hline Rectum & 64 & 45.7 \\
\hline Cecum and ascending colon & 30 & 21.4 \\
\hline Sigmoid colon & 21 & 16.4 \\
\hline Descending colon & 19 & 13.6 \\
\hline Transverse colon & 6 & 4.3 \\
\hline
\end{tabular}


When our cases were examined according to local recurrence and metastasis during diagnosis or follow-up; it was determined that local recurrence developed in $15(10.7 \%)$ of 140 cases, metastasis was detected at the time of diagnosis in 39 (27.9\%), and metastasis developed during clinical follow-up in 11 cases (7.8\%).

When the latest cases of our cases were examined; of the 140 cases, $89(63.6 \%)$ were in remission, $20(14.3 \%)$ were in relapse stage and $31(22.1 \%)$ died due to various reasons. When our cases were evaluated in terms of overall follow-up, overall survival and diseasefree survival; mean follow-up duration was $23.46 \pm 2.16$ months, mean overall survival was $103.83 \pm 14.53$ months and median overall survival was $66.00 \pm 7.21$ months, mean disease-free survival was $27.2 \pm 4.1$ months and median disease-free survival time was 13.0 \pm 1.5 months.

Serum hemoglobin (HGB) levels, white blood cell (WBC), platelet (PLT) count, red blood cell distribution width (RDW), and mean erythrocyte volume (MCV) values of 57 patients who received adjuvant chemotherapy before and after treatment were investigated (Table 2).

Table 2. Alterations in hematological parameters after adjuvant chemotherapy

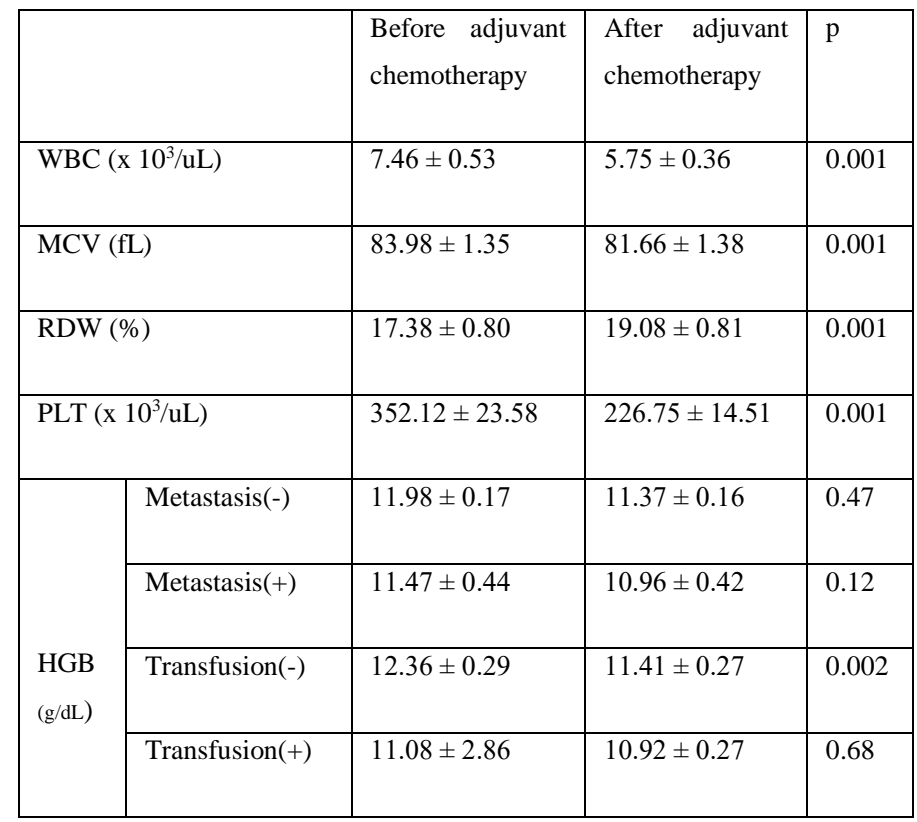

When the changes in hemoglobin (HGB) levels after adjuvant chemotherapy were examined; it was determined that HGB levels were decreased in patients with and without blood transfusion and this decrease was significant in the group without blood transfusion $(\mathrm{p}=0.002)$. In other words, the decrease in hemoglobin levels due to chemotherapy in blood transfusions is partially preserved. The decrease in HGB in the metastatic and non-metastatic groups was similar and there was no significant effect of metastasis on blood HGB levels $(p=0.776)$. There was no significant effect of chemotherapy duration on HGB levels ( $\mathrm{p}=$ 0.476).

There was a significant decrease in WBC levels after adjuvant chemotherapy $(\mathrm{p}=0.002)$ and this decrease was not affected by metastasis $(\mathrm{p}=0.576)$; In other words, WBC values were significantly decreased in all patients with or without metastasis, after adjuvant chemotherapy. While the effect of blood transfusion on WBC levels was not significant $(\mathrm{p}=0.589)$, the effect of the duration of chemotherapy on WBC levels was also not significant $(\mathrm{p}=0.796)$.

Mean erythrocyte corpuscular volume levels decreased significantly after adjuvant chemotherapy $(\mathrm{p}=0.001)$, this decrease remained the same in patients with and without metastasis $(p=0.230)$, and in patients with and without blood transfusion $(\mathrm{p}=0.563)$. There was no significant relationship between the duration of chemotherapy and MCV levels (p $=0.200$ ).

It was found that erythrocyte distribution width (RDW) levels increased significantly after adjuvant chemotherapy $(\mathrm{p}=0.001)$, this increase remained the same in patients with and without metastasis $(\mathrm{p}=0.935)$, and this increase was similar in patients with and without blood transfusion $(\mathrm{p}=0.222)$. There was no significant relationship between chemotherapy duration and RDW levels $(\mathrm{p}=$ $0.522)$.

When the changes in PLT levels were evaluated in patients receiving adjuvant chemotherapy; there was a significant decrease in PLT levels calculated after chemotherapy without considering the modifying factors $(\mathrm{p}=$ $0.001)$. This decrease was similar in the group with and without metastasis $(\mathrm{p}=0.082)$ and in the group with and without blood transfusion 
( $\mathrm{p}=0.067)$. In this case, we can say that metastasis and blood transfusion have no significant effect on PLT levels. In addition, there was no significant relationship between the duration of chemotherapy and PLT levels $(\mathrm{p}=0.626)$.

\section{DISCUSSION}

There was a significant decrease in WBC, $\mathrm{Hgb}, \mathrm{MCV}$ and PLT levels after adjuvant chemotherapy and this decrease was not affected by metastasis, duration of chemotherapy and blood transfusions. It was observed that MCV levels decreased significantly after adjuvant chemotherapy, and this decrease was found to be the same in patients with and without metastasis, and in those with and without blood transfusion. RDW levels were found to be significantly increased after adjuvant chemotherapy, this increase was found to be the same in patients with and without metastasis, and in those with and without blood transfusion. There was no significant relationship between chemotherapy duration and RDW levels. These data were also in agreement with the bone marrow suppressing properties of adjuvant chemotherapy. In addition elevated RDW values after chemotherapy may be showing the inflammatory response of the body.

Adjuvant chemotherapy has been shown to be beneficial on recurrence and survival in patients with colorectal cancer $(4,5)$. The mostly prescribed chemotherapy regimen was FUFA in this group of patients. FUFA is known to be well-tolerated with mild toxicities (6). Myelosupression and gastrointestinal side effects are the main side effects associated with FUFA treatment (7). Unfortunately, chemotherapy induced anemia and or thrombocytopenia is a common problem in oncology clinics (8). Severe neutropenia or anemia is not common associated with FUFA and we also did not determine severe clinical alterations in hemoglobin and WBC count levels in patients treated with FUFA (9). However, we determined a significant decrease in WBC levels after adjuvant chemotherapy which was not affected by the presence of metastasis, blood transfusions or the duration of chemotherapy.

Chemotherapy-induced thrombocytopenia is one of the most important causes of

Adress for correspondence: Dr Abdurrahman Yurtaslan Onkoloji Hastanesi Ankara - Türkiye e-mail: benankasapoglu@hotmail.com

Available at www.actaoncologicaturcica.com

Copyright $\odot$ Ankara Onkoloji Hastanesi thrombocytopenia in patients with cancer. Persistent and severe thrombocytopenia may cause life-threatening complications. Ten et al (10) reported that the overall thrombocytopenia frequency was $21.8 \%$ in 614 patients receiving different chemotherapy regimens and the highest frequencies of thrombocytopenia were defined in patients receiving carboplatin therapy. Hitron et al (11) investigated the results of 254 patients receiving 278 chemotherapy regimens and reported that, the incidence of clinically significant chemotherapy induced thrombocytopenia was present in $10.1 \%$ of patients. Inanc et al (12) reported a decrease in platelet count and mean platelet volume, but an increase in MCV levels in patients who received oxaliplatin (XELOX) and Bevacizumab combination therapy for colorectal cancer. In our study, we also determined a significant decrease in PLT levels calculated after chemotherapy regardless of the duration of chemotherapy, metastasis or blood transfusion effects.

Recently MCV has been studied in patients treated for colon cancer. Inanc et al reported a significant increase in MCV levels after Capecitabine- based chemotherapy in patients with metastatic colorectal cancer which can be considered as a predicting factor for treatment response (13). Scarabelli et al (14) also reported similar results with a significant increase in MCV levels in patients with breast or colon ca who were treated with Capecitabine. However we determined a significant decrease in MCV levels in patients with colon cancer who were treated with FUFA.

Red cell distribution width is known to be associated with systemic inflammation (15). Increase in RDW values have been suggested as a diagnostic and prognostic tool in colon cancer patients $(16,17)$. Very recently, in a meta-analysis of 49 studies, elevated pretreatment RDW level was suggested as a negative predictor for cancer prognosis (18). We determined a significant increase in RDW values after chemotherapy which may be associated with increased inflammatory response.

There are some limitations of this study that should be mentioned. First is the low number of patients and secondly we did not analyze the association of these alterations in 
blood parameters with the prognosis of patients.

In conclusion, chemotherapy induced alterations in complete blood count parameters are obvious and should be taken into account by the clinicians. The association of these alterations in blood parameters with the prognosis of patients should be investigated in further studies.

\section{REFERENCES}

1. Ferlay J, Soerjomataram I, Dikshit R, Eser S, Mathers C, Rebelo M, Parkin DM, Forman D, Bray F. Cancer incidence and mortality worldwide: sources, methods and major patterns in GLOBOCAN 2012. Int J Cancer. 2015 Mar 1; 136(5):E359-86.

2. Lopes-Serrao MD, Ussery SM, Hall RG 2nd, Shah SR. Evaluation of chemotherapy-induced severe myelosuppression incidence in obese patients with capped dosing. J Oncol Pract. 2011 Jan;7(1):13-7

3. Ades S. Adjuvant chemotherapy for colon cancer in the elderly: moving from evidence to practice.Oncology (Williston Park). 2009 Feb;23(2):162-7.

4. Scheithauer W, McKendrick J, Begbie S J et al. Oral capecitabine as an alternative to i.v. 5-fluorouracil-based adjuvant therapy for colon cancer: safety results of a randomized, phase III trial. Ann Oncol 2003;14:17351743.

5. Andre T, Boni C, Mounedji-Boudiaf L et al. Oxaliplatin, fluorouracil and and leucovorin as adjuvant tretament for colon cancer. N Engl J Med 2004;350:2343-2351.

6. Zaniboni A, Labianca R, Marsoni S, Torri V, Mosconi P, Grilli R, Apolone G, Cifani S, Tinazzi A. GIVIO-SITAC 01: A randomized trial of adjuvant 5-fluorouracil and folinic acid administered to patients with colon carcinoma--long term results and evaluation of the indicators of health-related quality of life. Gruppo Italiano Valutazione Interventi in Oncologia. Studio Italiano Terapia Adiuvante Colon. Cancer. 1998 Jun 1;82(11):2135-44.

7. Alberts SR, Sargent DJ, Nair S, et al. Effect of oxaliplatin, fluorouracil, and leucovorin with or without cetuximab on survival among patients with resected stage III colon cancer: a randomized trial. JAMA. 2012;307:1383-93.

8. Tas F, Eralp Y, Basaran M, Sakar B, Alici S, Argon A, Bulutlar G, Camlica H, Aydiner A, Topuz E. Anemia in oncology practice: relation to diseases and their therapies. Am J Clin Oncol. 2002 Aug;25(4):371-9.

9. Glimelius B, Ristamaki R, Kyaer $\mathrm{M}$ et al: Irinotecan combined with bolus 5-fluorouracil and folinic acid Nordic schedule as I line therapy in advanced colorectal cancer. Ann Oncol 13: 1868- 1873, 2002.

10. Ten Berg MJ, van den Bemt PM, Shantakumar S, Bennett D, Voest EE, Huisman A, van Solinge WW, Egberts TC. Thrombocytopenia in adult cancer patients receiving cytotoxic chemotherapy: results from a retrospective hospital-based cohort study. Drug Saf. 2011 Dec 1;34(12):1151-60.

11. Hitron A, Steinke D, Sutphin S, Lawson A, Talbert J, Adams V. Incidence and risk factors of clinically significant chemotherapy-induced thrombocytopenia in patients with solid tumors. J Oncol Pharm Pract. 2011 Dec;17(4):312-9.

12. Inanc M, Duran AO, Karaca H, Berk V, Bozkurt O, Ozaslan E, Ozkan M. Haematologic parameters in metastatic colorectal cancer patients treated with capecitabine combination therapy. Asian Pac J Cancer Prev. 2014;15(1):253-6.

13. Inanc $M$, Duran $A O$, Karaca $H$, Berk $\quad V$, Bozkurt O, Ozaslan E, Ozkan M. Haematologic parameters in metastatic colorectal cancer patients treated with capecitabine combination therapy. Asian Pac J Cancer Prev. 2014;15(1):253-6.

14. Scarabelli L, Giovanardi F, Gervasi E, Prati G, Pezzuolo $\mathrm{D}$, Scaltriti L. Increased mean corpuscular volume of red blood cells in patients treated with capecitabine for advanced breast and colon cancer. Chemotherapy. 2013;59(5):369-72.

15. Goyal H, Lippi G, Gjymishka A, John B, Chhabra R, May E. Prognostic significance of red blood cell distribution width in gastrointestinal disorders. World $\mathbf{J}$ Gastroenterol. 2017 Jul 21;23(27):4879-4891

16. Ay S, Eryilmaz MA, Aksoy N, Okus A, Unlu Y, Sevinc B. Is early detection of colon cancer possible with red blood cell distribution width? Asian Pac J Cancer Prev. 2015;16(2):753-6.

17. Yang D, Quan W, Wu J, Ji X, Dai Y, Xiao W, Chew H, Sun Z, Li D. The value of red blood cell distribution width in diagnosis of patients with colorectal cancer. Clin Chim Acta. 2018 Apr;479:98-102.

18. Wang PF, Song SY, Guo H, Wang TJ, Liu N, Yan CX. Prognostic role of pretreatment red blood cell distribution width in patients with cancer: A meta-analysis of 49 studies.J Cancer. 2019 Jul 10;10(18):4305-4317 